\title{
Opposition ved Kaj Mogensens forsvar for disputatsen: Livet - det dejligste eventyr. H.C. Andersens teologi
}

\author{
Professor em., dr.theol. \\ Kirsten Nielsen, Aarhus Universitet
}

\begin{abstract}
This article is a short version of my opposition at Kaj Mogensen's public defense of his doctoral dissertation, Life - the most wonderful story. The theology of H.C. Andersen. While most scholars have concentrated their studies on only one genre, Kaj Mogensen analyzes Andersen's most important novels The two Baronesses, To be or not to be and Lykke-Peer, the long drama "Ahasverus" and various poems and hymns as well as a few of his fairy tales. Mogensen reads the texts in their cultural context and argues that Andersen's theology is a challenge to modern theology. At the public defense, I challenged Mogensen to discuss his understanding of Andersen's use of intertexts and Mogensen's own criteria for including intertexts (often biblical intertexts) in his interpretations.
\end{abstract}

Keywords: Kaj Mogensen - the theology of H.C. Andersen - The fairy Tale of my Life - doctoral dissertation - opposition at public defense intertextuality - interpretation.

Cand.theol. og forhenværende sognepræst Kaj Mogensen forsvarede 9. maj 2018 sin disputats, Livet - det dejligste eventyr. H.C. Andersens teologi for den teologiske doktorgrad. Afhandlingen var forud for forsvaret blevet publiceret i to bind på i alt 1172 sider, ${ }^{1}$ hvor Kaj Mogensen behandler H.C. Andersens teologi, som den kommer til udtryk gennem det samlede forfatterskab.

Af en teologisk doktorafhandling kræves, at forfatteren fremlægger en tese (eventuelt flere teser), som undervejs afprøves på det valgte materiale. Emnet skal være teologisk relevant, og afhandlingen skal bidrage med ny viden, som fører forskningen et væsentligt skridt videre. Det kræves, at forfatteren redegør for de anvendte metoder, og

1. Kaj Mogensen, Livet - det dejligste eventyr. H.C. Andersens teologi (København: Eksistensen 2017). 
at argumentationen er lødig, så andre forskeres synspunkter fremstilles loyalt med tilslutning eller kritik. Dertil kommer kravet om akribi såvel i henvisninger som i referater af andre forskeres synspunkter. $\mathrm{Og}$ samlet set skal afhandlingen være på internationalt niveau.

\section{Afhandlingens tese og indhold}

Det er afhandlingens hovedtese, "at H.C. Andersenteksterne er så teologisk indholdsrige og betydningsfulde, at de kan berige kristendomsforståelsen $i$ mange sammenhange. Der er $i$ H.C. Andersenteksterne en teologi, som er en udfordring til fagteologien, til kulturlivet $i$ bredeste forstand, til etik og menneskesyn i vor tid" (s. 19-20 i den trykte bog). H.C. Andersens teologi drejer sig først og fremmest om den kærlige Guds forsyn og om udødelighedstanken. At Guds forsyn spiller en afgørende rolle, fremgår ikke mindst af de udførlige analyser af romanerne De to Baronesser og At vare eller ikke vare. Forsynstanken kombineres desuden med andre bibelske motiver som udvælgelse, menneskets frihed, skabelse og forsoning. Forsynstanken spiller også en vigtig rolle i flere af H.C. Andersens digte.

Udødelighedstanken er et centralt tema i At vare eller ikke vare, og troen på Guds kærlighed og mennesket som Guds elskede skabning medfører, at H.C. Andersen afviser tanken om en dobbelt udgang med både en himmel og et helvede. Netop diskussionerne om den dobbelte udgang har spillet en vigtig rolle i teologihistorien og skaber stadig debat, en debat som Kaj Mogensen selv gennem årene ihærdigt har bidraget til.

Med til Kaj Mogensens tese hører, at H.C. Andersen udfolder en selvstændig teologi set i forhold til sin tids teologiske og filosofiske strømninger, og at denne teologi også kan fungere som kritisk udfordring i dag. Og her peger Kaj Mogensen bl.a. på synet på Guds rolle ved konfirmationen, H.C. Andersens kristne humanisme samt hans, ifølge Kaj Mogensen, originale løsning på forholdet mellem tro og tænkning.

Afhandlingen beskæftiger sig, overordnet set, med forholdet mellem Gud og menneske, dvs. med H.C. Andersens gudsbillede og dets konsekvenser for mennesket, om tilværelsens dybe mening og sammenhæng. At der er tale om et kristent tilværelsessyn dokumenteres undervejs, hvor Kaj Mogensen igen og igen viser, at bestemte bibelsteder, f.eks. Sl 139 og 1 Kor 13 eller teologiske dogmer som forholdet mellem lov og evangelium, er afgørende for H.C. Andersens teologi. Ud fra et teologisk synspunkt er det desuden vigtigt, at H.C. Ander- 
sen inddrager de to erkendelseskilder, som har spillet en central rolle gennem hele teologihistorien: Bibelen og naturen.

Når afhandlingen har teologisk relevans, skyldes det endelig, at H.C. Andersen har haft stor indflydelse på dansk kultur. Kaj Mogensens afhandling kan derfor bidrage til øget viden om den kultur, som den samtidige teologi og H.C. Andersen var i diskussion med. En række ekskurser viser således Kaj Mogensens store indsigt i samtidens teologiske og filosofiske diskussioner.

Kaj Mogensens afhandling bidrager, som det kræves af en disputats, med ny viden, som fører forskningen et væsentligt skridt videre. Her skal jeg først og fremmest henvise til, at Kaj Mogensen ikke blot behandler en enkelt af de genrer, H.C. Andersen benytter sig af. Han analyserer de vigtigste romaner, dramaet Ahasverus, et stort antal af H.C. Andersens digte samt et mindre udvalg af eventyrene. Set i forhold til tidligere forskning er det store udvalg af tekster et væsentlig fremskridt. Desuden gør Kaj Mogensen opmærksom på, at det er sparsomt med "detaljerede værkanalyser", ligesom der mangler indgående litteraturvidenskabelige analyser af digtene, selv om H.C. Andersen er en af de betydeligste danske lyrikere.

Kaj Mogensen kan derfor med sin inddragelse af hele forfatterskabet vise, hvordan H.C. Andersens teologi er en rød tråd gennem forfatterskabet, selv om han ikke lægger skjul på, at der er stor forskel på, hvor meget teologien fylder i de forskellige værker.

\section{Kritik af afhandlingens metodeafsnit}

Som enhver afhandling har også Kaj Mogensens afhandling sine svage sider. Jeg skal her især pege på Kaj Mogensens metodeafsnit. Kaj Mogensen beskriver sine metoder som velkendte inden for den klassiske eksegese og peger på, at de ikke adskiller sig meget fra de metoder, som litteraturkritikere anvender. Teksterne tolkes i deres helhed, hvorfor de enkelte tekster læses intertekstuelt som del af såvel H.C. Andersens forfatterskab som af samtidens filosofiske og teologiske strømninger. Kaj Mogensen nævner desuden, at det er nødvendigt at inddrage indsigter fra flere metoder. "Brug af en enkelt metode kan indsnævre og begrænse fortolkningsresultaterne." (s. 18). Og som relevante metoder nævnes bl.a. "semio-litterær kritik, retoriske analyser og læsninger ud fra sociologiske, psykologiske, psykoanalytiske og biografiske synsvinkler." Dertil kommer den historisk-kritiske metode $\mathrm{i}$ et vist omfang, desuden narratologien, de intertekstuelle læsninger og den hermeneutiske tilgang, hvor det drejer sig om, at 
fortolkerens forudforståelse og teksten forenes i det, Gadamer kalder "Horizontverschmeltzung" (s. 22). Det lyder imponerende, men efter min bedste vurdering er der snarere tale om "name-dropping" end om en redegørelse for metoder, der reelt anvendes i afhandlingen.

På side 19 skriver Kaj Mogensen bl.a., at de valgte metoder "giver mulighed for at læse intertekstuelt" inden for forfatterskabet; de sætter teksterne ind i en tidsmæssig sammenhæng, ikke mindst ved hjælp af de tekster, som H.C. Andersen lader indgå i sine egne tekster, og de "tillader, at der drages 'anakronistiske' sammenstillinger, så der kan trækkes tråde op til nutidige problemstillinger og senere forfattere”. Og så følger denne præcisering:

Jeg anser det også for videnskabeligt at overskride en objektiverende og neutral videnskabsforståelse. Jeg er opmærksom på, at det, som al anden brug af tekster, kræver selvdisciplin. Et forfatterskab er også dets virkningshistorie, både i dets reception hos den enkelte læser og i dets prægning i eftertiden (s. 19).

Beskrivelsen af denne tilgang er vigtig for forståelsen af Kaj Mogensens arbejdsform, men det er en mangel, at han i sine analyser ikke redegør for, hvilke former for intertekster han opererer med. Afhandlingen rejser derfor det spørgsmål: Hvilke kriterier kan en forsker bruge, når han eller hun inddrager intertekster? Uden en sådan præcisering udsætter forskeren sig for at blive anklaget for vilkårlige valg af intertekster.

Her havde det været afklarende, om Kaj Mogensen havde skelnet klart mellem følgende tre niveauer: På det forste niveau gælder det intertekster, som forfatteren selv henviser til. På det andet niveau drejer det sig om den redaktionelle kontekst i bred forstand, ikke blot placeringen af fx et digt i en digtsamling, men også en salmes liturgiske placering. Og på det tredje niveau gælder det intertekster, som er yngre end forfatterskabet og derfor alene inddrages af læseren (i dette tilfælde Kaj Mogensen).

På det første niveau, hvor forfatteren selv markerer, at her skal læseren inddrage en intertekst, er brugen af citater et godt eksempel. Citatet er en klar markør. Ethvert citat er hentet fra en kontekst, og derfor skal vi forholde os til såvel selve citatet som til den kontekst, det er taget fra. Når det drejer sig om H.C. Andersens tekster, vil det ofte være brugen af bibelcitater, eller som det er tilfældet i romanen At vare eller ikke vare, Faustmyten.

Andet niveau af intertekstualitet drejer sig om det redaktionelle niveau, hvor placeringen af en tekst i en større sammenhæng medfører, at de omgivende tekster fungerer som intertekster, der skal tænkes 
med i fortolkningen. Her vil nogle af Kaj Mogensens overvejelser over rækkefølgen af H.C. Andersens forskellige udgivelser høre hjemme og vel at mærke med den pointe, at forfatteren undertiden også er redaktør af sine egne værker. Det kunne være placeringen af "Grantræet" før "Sneedronningen”. Og her får placeringen teologiske konsekvenser. "Grantræet" slutter med, at alt er forbi, mens "Sneedronningen" begynder med ordene "See saa! Nu begynde vi....", hvilket ifølge Kaj Mogensen repræsenterer "frelsens nåde". Den omvendte rækkefølge ville derfor ikke give mening ud fra H.C. Andersens teologi (s. 951-952 ). Kaj Mogensen nævner også, at Lykke-Peer netop som eventyr afrunder romanerne, men det bliver desværre ikke klart, om det har teologiske konsekvenser (se s. 595).

På det tredje niveau inddrages intertekster, som er yngre end den pågældende tekst, og hvis inddragelse derfor ikke kan være intenderet af forfatteren. Og her er det ikke særlig klart, hvad Kaj Mogensen mener med at tale om "anakronistiske sammenstillinger", og om at "Et forfatterskab er også dets virkningshistorie, både i dets reception hos den enkelte læser og i dets prægning af eftertiden” (s. 19). For er det i denne kategori, vi bl.a. skal placere de mange henvisninger til moderne teologer? Og er det bl.a. derfor, Kaj Mogensen s. 33 kan tale om, at en fortolkning kan være klogere end selve forfatterskabet? Kaj Mogensen skriver i sin tolkning af H.C. Andersens "Passions-Sang" (s. 842), at der ikke er tale om nogen form for forsoning, da der intet er at forsone, og så tilføjer han: "Skal der indsættes en forsoningstro i digtet, må læseren selv gøre det.” Umiddelbart virker det i sammenhængen ikke som noget, han opfordrer til, men det er vel netop et eksempel på, at forskellige læsere vil inddrage egne intertekster?

\section{H.C. Andersens digte}

Kaj Mogensen er den første, der har analyseret så stor en mængde af H.C. Andersens enkeltdigte, hvilket selvfølgelig indebærer, at nogle af dem ikke tidligere har været behandlet af forskerne. Der er dog naturligvis tale om et begrænset udvalg af H.C. Andersens over 1000 digte, da en meget stor del af lyrikken ikke er specielt relevant for en analyse af teologien i H.C. Andersens forfatterskab (s. 604).

I sin udgave af H.C. Andersens samlede digte skriver Johan de Mylius i sit forord: ${ }^{2}$

2. H.C. Andersen. Samlede digte. Udgivet af Johan de Mylius, Aschehoug 2000. 
Kendetegnende for Andersen og for alt, hvad han har begået sig i, er åbenhed, modtagelighed, følsom registreringsevne, det hurtige og skarpe blik, mangesidighed, fastholdelse af psykiske grundpositioner parret med stadig udvikling og skyden ham. Skulle man have overset det, så er digtene også af den grund uundværlige til forståelsen af fænomenet H.C. Andersen" (s. 8).

\section{Passions-Sang}

H.C. Andersens åbenhed, modtagelighed og følsomme registreringsevne møder vi fx i digtet "Passions-Sang" (s. 833-842). H.C. Andersen angiver derudover, at det er "en Passions-Sang som Pifferrari i Rom synge den, under Fastetiden". I fodnote 638 hedder det: "H.C. Andersens passionsdigt er så forskelligt fra dansk passionsdigtning, at det må vare inspireret af katolsk tradition." Men så undrer det mig, at Kaj Mogensen ikke sætter sangen ind i en katolsk kontekst og viser, hvor den afspejler katolsk teologi. Man kunne få den mistanke, at Kaj Mogensen underbetoner den katolske indflydelse, fordi han gerne vil placere H.C. Andersen inden for den evangelisk-lutherske teologi. Det havde dog været relevant at pege på, at når vi i strofe 9 kan læse om inkarnationen og nadveren, hører vi i sangen ikke om blodet, men blot om alterbrød og Jesu legeme, selv om Jesu blod spiller en vigtig rolle i digtet.

Salmen handler om Jesu bønskamp i Getsemane Have, hvor Jesu blod trængte "frem som Vande, Stod i Draaber paa min Pande, Det i Strømme flød for Dig..." (strofe 1; jf. Luk 22,44). Senere i sangen møder vi igen motivet med vandet, der strømmer ud, men nu af den dødes krop, da soldaten har stukket sit spyd i siden på Jesus. H.C. Andersen skriver i strofe 6 (s. 835):

Spydet jog de i min Side,

Og fra den udstrømmed' Vandet,

Dødens tegn. Var det vel andet?

Livets Tegn det var for Dig!

Kaj Mogensen gør opmærksom på, at vi i denne strofe skal inddrage Joh 4,13-14, som er led i fortællingen om den samaritanske kvinde, som Jesus taler med ved Jakobs brønd, og hvor Jesus selv kalder sig en kilde til evigt liv. Og denne henvisning til Johannesevangeliet som intertekst i strofen om vandet, der skaber liv, er virkelig oplysende. I første strofe er det blodet, der trænger frem som vande, hvorved omfanget af Jesu lidelse understreges. I strofe 6 bliver det vand, der flyder fra Jesu døde krop, til livets vand. Vandet får en mer-betydning eller en symbolsk betydning, som Kaj Mogensen kalder det. 
Kaj Mogensen nævner meget kort på s. 836, at der også kan være tale om, at blod og vand har en sakramental betydning. "Nadver og dåb har deres grund i Jesu død", hedder det. Fra billedkunsten kender vi eksempler på, at vandet fra Jesu side løber direkte ned i alterkalken. Jeg kan derfor nemt forestille mig, at H.C. Andersen har set nogle af disse korsfæestelsesbilleder og associeret fra dødens vand til livets vand. Men jeg har svært ved at se den korte omtale af dåben som andet end Kaj Mogensens egen association. Jeg savner med andre ord en markør i teksten, der peger på netop dåben. Eller en klar tilkendegivelse af, at nu befinder vi os på det niveau, hvor det drejer sig om læserens egne associationer.

Det er en meget vigtig pointe for Kaj Mogensen, at Passions-Sangen i modsætning til fx Kingos passionssalmer slet ikke omtaler menneskets synd. Og det er korrekt, at vi ikke støder på formuleringer som: "Forlad for Jesu Vunder, / Vor Synd, o milde Gud!" (s. 837). Fokus er på Jesu lidelse for den enkelte, som opfordres til at tænke på, hvad Jesus har gjort for ham eller hende. Der er ingen opfordring til at bekende sine synder, men spørgsmålet er alligevel, om sangen ikke har som forudsætning, at det er det syndige menneske, Jesus henvender sig til og døde for. Hvis vi følger den tanke, at det er den johannæiske teologi, der ligger bag sangen, må vi ud fra netop dette evangelium sige, at synd er, "at de ikke tror på mig" (Joh 16,10). Johannesevangeliet er da også skrevet, "for at I skal tro, at Jesus er Kristus, Guds søn, og for at I, når I tror, skal have livet i hans navn" (Joh 20,31).

Hvis vi læser det gentagne udbrud i hver strofe i H.C. Andersens digt: "Mon Du vel tænker paa mig!" med Johannesevangeliet som intertekst, så er det efter min mening netop en opfordring til at tænke på Jesus og indse, hvad Jesu lidelse og død betyder. Så ja, det er en anderledes måde at henvende sig til det syndige menneske på, end når man nævner dets synd og skyld. Det er en henvendelse til den, der må spørge sig selv, om han eller hun har begået den afgørende synd: ikke at tro at Jesus er Kristus.

Kaj Mogensen gør opmærksom på, at strofe 10 er "det tætteste H.C. Andersen kommer en dogmatisk formulering” (s. 840). Strofen lyder:

\footnotetext{
Naar jeg, som Gjenløsnings-Summen,

Selv mig hengav her paa Jorden.

Hist jeg Livets Sum er vorden,

Hist jeg Lønnen er for Dig!

Vee!

Mon Du vel tænker paa mig!
} 
"Gjenløsnings-Summen” forstår Kaj Mogensen som "den sum, som Jesus betalte for at genløse det tiltalte menneske”. Tanken er, at mennesket er sat i fangenskab. Kaj Mogensen nævner, at ud fra Romerbrevet 6-8 kan dette fangenskab forstås om "synden, loven og døden", eller man kan tænke på Djævelens fangenskab, sådan som Luther taler om det. Videre drøfter Kaj Mogensen ordene "Livets Sum" og "Lønnen" og tolker dem på baggrund af Matt 5,18, hvor der står, at de troendes løn skal blive stor i himmelen. Og Kaj Mogensen konkluderer: "Jesu selvhengivende karlighed, således som den blev udfoldet $i$ hans lidelse og død, betinger således evigt liv for det tiltalte menneske".

Kaj Mogensen peger med rette på disse bibelsteder, men når det kommer til konklusionen, så undrer det mig, at Kaj Mogensen ikke giver sin egen tolkning af, hvad det er for et fangenskab, det tiltalte menneske er blevet befriet fra eller løskøbt fra. Mennesket er jo netop tiltalt, så hvad er mennesket tiltalt for?

\section{Barn Jesus i en krybbe lå}

Bedst kendt af H.C. Andersens salmer er nok "Barn Jesus i en krybbe lå” (s. 807-810). Kaj Mogensen skriver bl.a. om salmen: "I flertallet af de samtidige julesalmer er glæden begrundet i inkarnationen og frelsen ved syndernes forladelse. Det er der intet af i H.C. Andersens salme. Den er enkel og udogmatisk, men på ingen måde overfladisk" (s. 808). Det er korrekt, at der ikke tales om syndernes forladelse, men salmen handler sandelig om inkarnationen. Kort forinden på samme side kan man læse, at salmen på en smuk og enkel måde udtrykker, "hvad der $i$ den kristne tankning ofte er udfoldet spekulativt: At Jesus Kristus er sand Gud og sandt menneske". Salmen indeholder ikke dogmatiske ord som "inkarnation" eller "sand Gud og sandt menneske", men glæden er tydeligvis begrundet i, at den inkarnerede Gud nu ligger i en krybbe som et jordisk barn, "Skjøndt Himlen var hans Eie".

\section{Jeg har en angst som aldrig for}

"Jeg har en angst som aldrig før", er en anden af H.C. Andersens salmer (s. 894-902). Kaj Mogensen giver først en fin gennemgang af selve angstmotivet i første strofe og går bl.a. ind på baggrunden i H.C. Andersens eget liv. Derudover nævner Kaj Mogensen de mange bibelsteder, som teksten "henspiller på”, som det hedder. Skildringen af angsten i første strofe ser Kaj Mogensen som en parallel til beretningen om Jesus i Getsemane have (Mark 14,33f). I strofe to, hvor det hedder: "Alt Ondt i mig det kom fra mig", kan der "henspilles på Romerbrevet 7,18: "Thi jeg veed, at i mig, det er, i mit Kiød, boer ikke Godt" (s. 899). Derudover peger udtrykket "mit eget Skyldner-Brev" tilbage på Jesu lignelse om den uærlige godsforvalter i Luk 16,1-13. 
I tredje strofe, hvor H.C. Andersen skriver: "Jeg trædes skal af Dødens Hæl", henspilles der på "syndefaldsfortællingen, hvor Gud sagde til slangen: 'Jeg vil sætte Fienskab imellem dig og imellem Quinden, og imellem din Sæd og imellem hendes Sæd; den samme skal sønderknuse dit Hoved, men du, du skal sønderknuse hans Hæl'” (1 Mos 3,15). Derudover peger Kaj Mogensen på 1 Kor 15,26, hvor døden kaldes den sidste fjende. H.C. Andersen beder i linje tre om at få Fadervor lagt på sin tunge "som Duens Blad", så han kan blive glad. Kaj Mogensen forbinder dette billede med Syndflodsfortællingen, hvor duen anden gang kom tilbage med et blad i næbbet som tegn på, at vandet var ved at trække sig tilbage.

Men hvordan skal disse intertekster tolkes? I strofe to hedder det: "De Andres Skyld jeg nok opskrev / Men ei mit eget Skyldner-Brev." Lignelsen om den uærlige godsforvalter (Luk 16,1-13) ligger som nævnt bag disse linjer. Lignelsen handler om en uærlig forvalter, der bliver afskediget af sin herre og derfor går til sin herres skyldnere og beder dem nedskrive deres gæld. På den måde skaffer han sig gode venner, som kan hjælpe ham til gengæld. H.C. Andersen bruger lignelsen anderledes, når han skriver, at han omhyggeligt opskrev, hvad de andre skyldte, men derimod ikke gjorde det samme med sin egen skyld. Formålet var at stille sig selv i et bedre lys end de andre: "Hvor har jeg for mig selv hver Dag / Besmykket godt min egen Sag."

Kaj Mogensen gør i sin gennemgang opmærksom på, at "I anden strofe fører angsten til en uforbeholden bekendelse af synd og skyld" (s. 899). H.C. Andersen bekender her sin farisæisme. Jeg er enig i, at H.C. Andersen bruger lignelsen på sin særlige måde, men her kunne det have været spændende, om Kaj Mogensen havde redegjort for, hvilken betydning det har for salmen, at det er en bibelsk tekst, der inddrages, og så netop bruges bevidst anderledes end lignelsen? Hvilken forskel gør det for tolkningen, om man kender referencen til lignelsen eller ej?

I første linje af strofe tre hedder det: "Jeg trædes skal af Dødens Hæl". Kaj Mogensen skriver som kommentar hertil: "Kun en person kan have en hæl. Der er uden tvivl association fra døden til slangen... Døden er som i 1 Korintherbrev 'den sidste fjende' (1 Kor 15,26). Den træder på mennesket.” Og herefter koncentrerer Kaj Mogensen sig om dødens rolle og sjælen, der løfter sig. Men hvorfor bruger H.C. Andersen udtrykket "Dødens hæl"? I Syndefaldsberetningen er der ingen, der bruger hælen til at træde med. I straffen over slangen hedder det derimod, at "kvindens afkom skal knuse dit hoved, og du skal bide hendes afkom i hælen" (1 Mos 3,15). Igen ville det være rart at vide, hvordan vi skal forstå denne henvisning til en bibelsk intertekst? Har H.C. Andersen blot en erindring om, at døden kom ind i verden 
i forbindelse med Syndefaldet, og at der var noget med en hæl, og så skaber han sit eget billede af dødens hæl, som tramper på ham? Eller er der tale om en bevidst ændring af den gamle fortælling? Eller skal Syndefaldsberetningen som intertekst blot give autoritet til H.C. Andersens egne ord ved at give dem en bibelsk klang?

I strofe tre linje tre beder H.C. Andersen:

Læg Fadervor som Duens Blad

Mig paa min Tunge, gjør mig glad.

Fadervor spiller en vigtig rolle ikke blot her, men, som Kaj Mogensen gør opmærksom på, også i fortællingen "Hvad hele Familien sagde", hvor Fadervor kaldes "Naadens Draabe" og "Trøstens Perle fra Gud" (s. 900). Og jeg er ganske enig i denne henvisning og i, at Fadervor skal trøste den bange, samt at "Duens Blad" henviser til Syndflodsfortællingen. Men jeg savner en nærmere redegørelse for, hvad det er i Fadervor, vi skal tænke på i netop denne salme. Hvad skal der trøstes for? Kaj Mogensen taler om, at nu er "den tid, der er mærket af angst og skyld”, ved at være ovre. Ja, og netop i denne salme, hvor der tales om skyld i strofe 2, og hvor strofe 3 henviser til såvel Syndefald som Syndflod, er det vel ikke irrelevant at overveje, om indholdet af Fadervor også er betydningsfuldt?

En af bønnerne lyder som bekendt: "Forlad os vor skyld, som også vi forlader vores skyldnere”. Kaj Mogensen gør det i sin gennemgang af strofe to helt klart, at der her er "en uforbeholden bekendelse af synd og skyld” (s. 899). Men er der ikke også i strofe tre, hvor interteksten er hentet fra beretningen om ødelæggelsen af den syndige verden, og Fadervor skal trøste den angste, tale om en erkendelse af syndens magt? Kaj Mogensen skriver s. 902: "Angsten er både hos Kierkegaard og H.C. Andersen genstandsløs.” Men holder det? Angsten har, så vidt jeg kan se, i denne salme så absolut sin genstand, nemlig synd og død. Trøsten skal derfor bestå i, at Gud befrir det syndige menneske for dets skyld. Og det gør Gud ved at lægge Fadervor på den bedendes tunge.

\section{Cantate afsjungen ved Comtesse Marie Moltkes Confirmation}

Mit sidste eksempel på Kaj Mogensens tekstanalyse er hentet fra H.C. Andersens "Cantate afsjungen ved Comtesse Marie Moltkes Confirmation i Bregentved Capel den 8de Juni 1844" (s. 851-863). Hvad der interesserer mig i denne sammenhæng er, at cantaten indgår i en liturgisk sammenhæng. Da den blev skrevet, var en meget vigtig del af konfirmationen konfirmandens eget ja-ord, men Kaj Mogensen understreger, at i denne cantate er det Gud, der giver, og konfirman- 
den, der modtager. Som det hedder s. 855: "Konfirmandens ja-ord er ikke nævnt i H.C. Andersens tekst." Og derved adskiller H.C. Andersens opfattelse sig fra datidens traditionelle opfattelse af konfirmationen som konfirmandens egen bekræftelse af dåbspagten.

Den hymne, der skal afsynges efter løftets aflæggelse, består af tre strofer og er primært en hyldest til Gud, men i strofe to hedder det: "Hun har Dig bekjendt herinde." Det er en klar henvisning til den handling, der er gået forud, hvor hun selv har bekræftet sin dåbs pagt. Alligevel tolker Kaj Mogensen hele cantaten således, at "Det er Gud, som alene indstifter pagten." Men for mig at se er ordene: "Hun har Dig bekjendt herinde" og hele den liturgiske kontekst tilstrækkeligt til at fastholde, at selv om H.C. Andersen primært bruger sin cantate til at hylde Gud, så betyder det ikke, at han ser bort fra konfirmandens bekendelse, endsige at deltagerne kun tænker på, hvad Gud har gjort, når de netop har overværet, at konfirmanden selv har sagt sit ja. Jeg vil derfor hævde, at sætningen om comtessens egen bekendelse, som er sket "herinde", peger tilbage på det, menigheden netop har overværet. Vi står altså over for en form for intertekstualitet, hvor den liturgiske kontekst fungerer som intertekst.

\section{Afrunding}

Ved forsvaret ønskede jeg at drøfte enhver eksegets grundspørgsmål: Hvordan fortolker man en tekst? Hvilken rolle spiller forfatterens egen intention og de intertekster, forfatteren mere eller mindre direkte inddrager i sin tekst? Hvilken rolle spiller de intertekster, som skabes af konteksten, den være sig en redaktionel kontekst eller en liturgisk kontekst? Og hvornår drejer det sig om den nutidige læsers egne intertekster? Disse spørgsmål førte til en samtale, der har bidraget til den respekt, jeg har for det store arbejde, der ligger bag Kaj Mogensens afhandling om H.C. Andersens teologi. Afhandlingen vidner om stor lærdom og om vilje til at delagtiggøre andre i, hvad Kaj Mogensen selv har fået ud af sit livslange følgeskab med en af vore betydeligste digtere. Dertil kommer, at Kaj Mogensen gennem sit arbejde har gjort en stor indsats for, at studiet af H.C. Andersens værker ikke blot skal omfatte teksternes betydning i datiden, men også blive brugt som afsæt for en samtale med og kritik af nutidig teologi. Jeg er således ikke i tvivl om, at det foreliggende arbejde, som velfortjent har ført til tildelingen af den teologiske doktorgrad, vil inspirere til videre studier og diskussioner. 